\title{
Applying the ground reaction curve concept to the assessment of shield support performance in longwall faces
}

\author{
Stanislaw Prusek ${ }^{1} \cdot$ Marek Plonka $^{2} \cdot$ Andrzej Walentek $^{2}$
}

Received: 1 June 2015 / Accepted: 18 September 2015 /Published online: 25 February 2016

(C) The Author(s) 2016. This article is published with open access at Springerlink.com

\begin{abstract}
The longwall method is used in many countries around the world in the underground extraction of coal seams. This method enables significantly improved production results to be achieved when compared to the bord and pillar mining system. However, this mining method requires higher capital investment compared to bord and pillar mining. One of the essential elements required to achieve the anticipated level of production from longwall panels is good shield-strata interaction. This means that the shields used in the longwall faces should have an adequate capacity to ensure the maintenance of roof stability in the longwall working. The issue of determining shield capacity has been the goal of research in many countries resulting in a number of different methods for calculating the required capacity of shields. In recent years, numerical modeling and ground reaction curves (GRCs) have been used to determine adequate shield capacity. An important factor to be considered in analyses using the concept of GRC for shield support selection for ground and mining conditions is roof convergence. This paper presents an analysis of shieldroof strata interaction in two longwall panels with natural roof caving in the gob using the concept of GRC. The GRCs for the specific mining conditions in the two longwall faces were determined by means of numerical modeling using Phase $^{2}$
\end{abstract}

Andrzej Walentek

awalentek@gig.eu

Stanisław Prusek

sprusek@gig.eu

Marek Płonka

mplonka@gig.eu

1 Central Mining Institute, Plac Gwarków, 140-166 Katowice, Poland

2 Department of Extraction Technologies and Mining Support, Central Mining Institute, Plac Gwarków 1, 40-166 Katowice, Poland software. Performance characteristics of two-leg shields were obtained from underground measurements conducted continuously during the retreat of the longwall panels. In a specially prepared measuring shield, the changes in the leg pressures were measured. In addition, the changes in shield geometry were assessed by means of inclinometers. For the two longwall panels studied, the selected variations of leg pressures and changes of shield height in time are presented for a single shield's cycle during the longwall operations for shield advance, setting, loading, and lowering. An analysis of the interaction between the shield and the roof strata rock mass was performed based on a comparison of the GRC and the operating characteristics of the shield. The values of the roof convergence, which occurred in the longwall faces during the single shield's cycle, are presented. It is strongly recommended that a system enabling the characterization and mining conditions appropriate for shield capacity determination and selection be developed.

Keywords Underground longwall mining $\cdot$ Shield-strata interaction $\cdot$ Ground reaction curve $\cdot$ Numerical modeling

\section{Introduction}

The longwall method, along with the bord and pillar system, is most commonly used in the underground mining of hard coal seams. The use of longwall methods involves considerable financial investment which has to be borne by the mine from the beginning. Financial expenditures relate, among others, to gate roads and set-up room development or the purchase of necessary longwall equipment such as shearers, shields, or an armored face conveyor (AFC). Significant expenses incurred by mining plants for longwall star-up lead to an expectation that the return on investment should be achieved in the 
shortest time possible. Unfortunately, unexpected geological and mining conditions often significantly delay production. Frequent face stoppages take place in longwalls for various reasons including roof falls and injuries/fatalities, which can sometimes bring the production process to a standstill for several days resulting in significant financial losses. For these reasons, several studies continue to be conducted to ensure the safe and efficient exploitation of hard coal seams. To achieve this goal, when a longwall system is adopted, one of the primary issues is the selection of adequate shields for the given ground conditions.

There has been a range of studies and underground observations by many researchers (Winstanley 1951; Dubois 1960; Herwig 1981; Jacobi 1981; Peng 1987; Frith 2005, 2013; Keim and Miller 1999; Das 2000; Payne 2008; Sastry and Nair 2009; Trueman et al. 2010; Prusek 2014) on the basis of which the impact of various geological or mining factors on the roof stability in longwalls can be determined. Based on these research findings, many theories and methods for calculating load on shield support in longwalls, shield support capacity, or methods enable the assessment of the conditions for maintaining the roof in longwalls (Płonka et al. 2003; Hussain et al. 2013; Wilson 1975; Smart and Redfern 1986; Biliński 1976; Jacobi 1981; Peng 2006; Barczak and Oyler 1991; Langosch et al. 2003; Özel and Ünal 1998). In the case of using shield support in longwalls in areas of outbursts or bumps, studies were conducted to assess the impact of these dynamic phenomena on shield support loads (Singh and Singh 2009b; Biliński 1983; Holub et al. 2011; Prusek et al. 2005a; Szweda 2003). In recent years, research on shield support-strata interaction in longwalls has been further supplemented by the use of numerical modeling (Hosseini et al. 2013; Manteqi et al. 2012; Singh and Singh 2009a, b; Saeedia et al. 2008; Prusek et al. 2005b; Yasitli and Unver 2005; Yavuz 2004; Gao et al. 2014; Shabanimashcool et al. 2014; Qing-Sheng Bai et al. 2014).

Data from monitoring systems (instrumentation) or shield control systems have provided significant enhancement to research related to the evaluation of shield performance at longwall faces. Different examples of analysis of shield-roof strata interaction, based on shield leg pressure data during longwall face advance, have been presented by a number of researchers (Peng 1998; Płonka and Rajwa 2011; Trueman et al. 2009; Wiklund et al. 2011). For instance, in Australian longwall faces, Longwall Visual Analysis (LVA) software is employed. This software enables the different analysis of collected shield pressure data including damage to the shield legs, changes in the shield set pressure, or the number of yield events in the support load cycle (Trueman et al. 2009, 2011). On the basis of the recorded shield leg pressure data, the concept of a method for early warning against roof falls on longwall faces was developed by Hoyer (2012).

For the selection of adequate parameters for shields in given geological and mining conditions, a ground reaction curve
(GRC) is used. GRCs show the relationship between roof convergence and pressure applied on the support (Brady and Brown 2006).

GRC concept is commonly used in tunnelling. It makes it possible to optimize selection of a tunnel support considering its load and convergence (Brady and Brown 2006). The course of GRC can be determined with analytical calculations, underground measurements and observations, or numerical modeling (Carranza-Torres and Fairhurst 2000; Medhurst 2005; Singh and Singh 2009a; Esterhuizen and Barczak 2006). A GRC starts at the value of in situ hydrostatic stress $\left(p_{\mathrm{o}}\right)$, in given geological and mining conditions, and most often consists of two parts. The first one is a straight line reflecting elastic strain of the rock mass (marked red in Fig. 1 between $p_{\mathrm{o}}$ and A). The other part of the curve (below point $\mathrm{A}$ to the end of the curve-marked black in Fig. 1) represents plastic strain of the rock mass. The determined course of changes in pressure and displacement of the rock mass described with a GRC is combined with load-deformation characteristics of a support. Figure 1 shows an example of selecting a support of stiffness $k$, which was installed in a roadway with circular cross-sectional shape. The support was installed after some time, at rock mass displacement $u_{i n}$. In point $\mathrm{B}$, the support characteristics intersect the course of GRC. It is the point of equilibrium where pressure $p_{e q}$ acts on the support and there is rock mass displacement $u_{e q}$ in the underground working (e.g., tunnel) (Oreste 2003).

In the papers (Mucho et al. 1999; Esterhuizen and Barczak 2006; Barczak et al. 2008), use of GRC concept to select

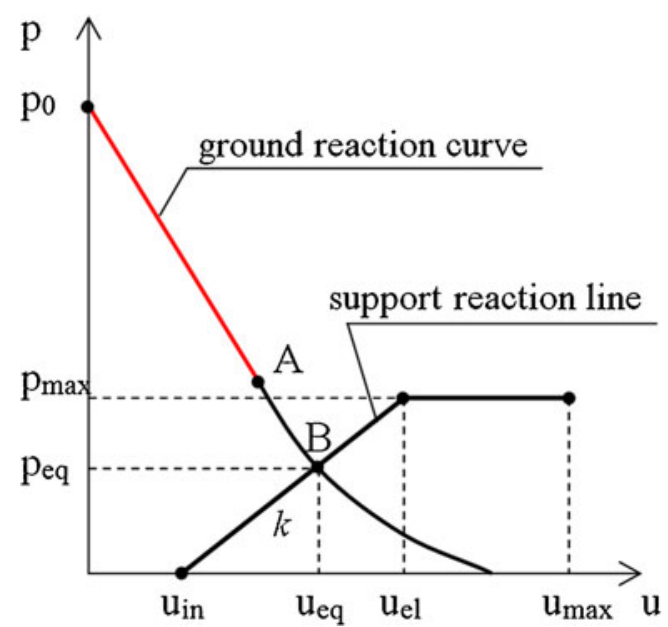

Fig. 1 Example of GRC concept in selecting support for a roadway with circular cross-sectional shape. $p$ internal tunnel pressure, $u$ radial displacement of the wall (positive toward the tunnel axis), $p_{0}$ in situ hydrostatic stress, $p_{e q}$ pressure acting on the support structure, $p_{\max }$ pressure that induces the plastic failure of the structure (support capacity), $k$ support stiffness, $u_{i n}$ displacement of the wall before support installation, $u_{e q}$ displacement at equilibrium, $u_{e l}$ displacement of the wall on reaching the elastic limit in the support, $u_{\max }$ displacement of the wall on collapse of the support, $B$ equilibrium point of the tunnel support system (Oreste 2003) 
support of tailgates, affected by abutment pressure in the longwall panel, has been presented. Authors described the process of selecting a standing support for tailgates where significant roof-to-floor convergence is observed. They showed that GRC concept makes it possible to optimize support selection, as it considers both load imposed on a support and the roof-to-floor convergence in the tailgate. Figure 2 shows GRCs at different distances to the longwall face line, determined with numerical calculations. Characteristics of two supports, A, a stiff (brittle) one, and B, a soft one (Esterhuizen and Barczak 2006), are compared with the GRCs.

Figure 2 shows that stiffer support A would be destroyed at the longwall face line. Therefore, it would not be able to limit convergence in a tailgate inby (behind) the face. Softer support $\mathrm{B}$ would be capable to control tailgate convergence as far as $60 \mathrm{~m}$ inby the longwall face. If it was used, tailgate convergence at the distance would be slightly over $200 \mathrm{~mm}$. If additional abutment pressure acted on the support $\mathrm{B}$, associated with advancing the next longwall in the panel (full extraction in Fig. 2), the support parameters would be insufficient to control convergence and the support would be destroyed.

Taking into account presented on Fig. 2 results, it can be concluded that, currently, there is no limitations in GRC application. It is so largely due to application of numerical methods which enable determining GRC course for any geomining conditions, including abutment pressure during longwall face advancing.

The use of the GRC concept for examining support performance in longwall faces in Australian mines was presented by Medhurst (2005). By using the results of measurements of roof convergence in longwall faces, recorded shield pressure data, and the results of the stability of longwall faces, Medhurst showed the influence of various factors on GRC and on the conditions for maintaining the roof in longwall

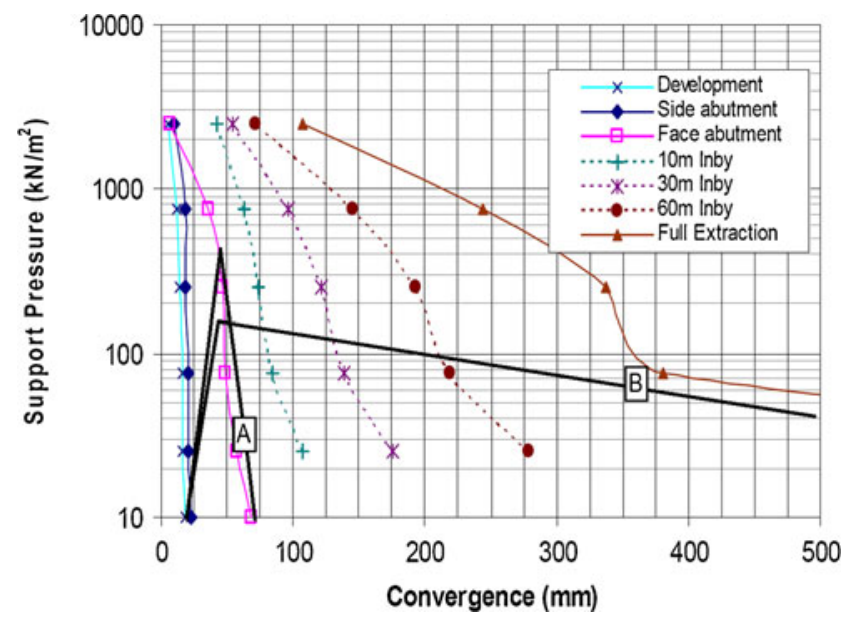

Fig. 2 Calculated GRCs for a tailgate at different distances to the longwall face line: $A$ a stiff (brittle) support, $B$ a soft support (Esterhuizen and Barczak 2006) workings. The factors analyzed by Medhurst include support capacity, depth of cover and the cutting height, coal seam strength and stiffness, canopy tip-to-face distance, retreat rate, weak immediate roof, and overburden massive strata. Medhurst emphasized the impact of support capacity, depth of cover, and cutting height on the change of the GRC curve and presented GRCs which indicated roof convergence increase with increasing cutting height and depth of cover.

Based on the GRC concept, Barczak and Tadolini (2006) have attempted to answer the question "Is bigger always better?" with reference to standing support in tailgate entry or shield support in longwalls. These authors presented data showing a steady increase in the capacities of shields used in the USA. In 2005, the maximum shield capacity had already reached $1300 \mathrm{t}$. The phenomenon of uncontrollable roof convergence, which GRC illustrates, is not always taken into account during shield selection forgiven mining conditions. The full loading cycle of shield support in a longwall with ground reaction (response) curves calculated for different situations during longwall operations is shown in Fig. 3.

Figure 3 shows all the elements affecting the roof convergence in the longwall working. The GRCs were developed to take into account the shearer cut from the face and adjacent shield release. The characteristic points from $\mathrm{A}$ to $\mathrm{F}$, which correspond to specific shield stages in the longwall, were presented against the background of these curves. Barczak and Tadolini's paper contains a number of interesting analyses referring to, among others, the impact of coal stiffness, support yielding, or the set pressure on the roof maintenance in the longwall working. In summary, the authors concluded that based on the GRC, the increase of shield capacity is beneficial since it reduces the value of roof convergence in a longwall working. On the other hand, however, they raise the question whether increasing the shield capacity is justified, taking into account the fact that GRCs show a slight reduction of roof convergence with a significant increase in support capacity (in the steep part of the GRC).

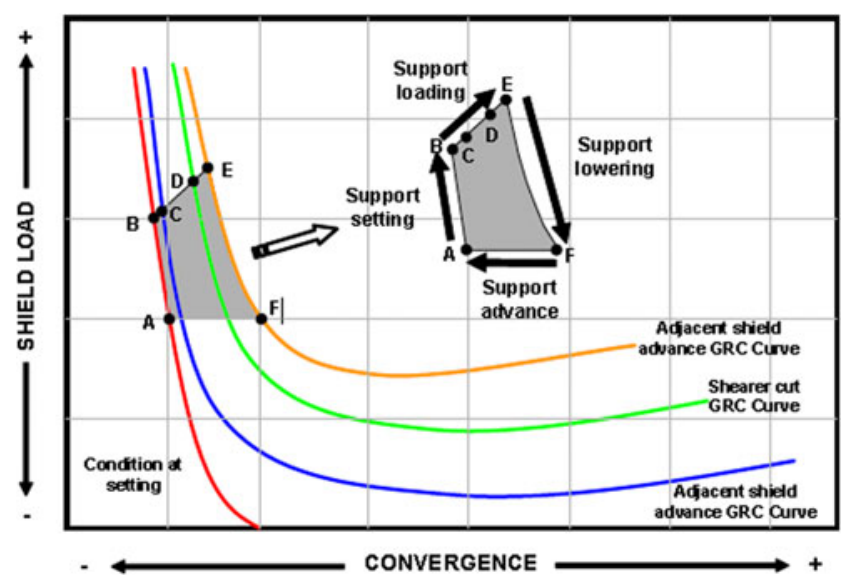

Fig. 3 Cycle loading pattern on ground reaction curve for shield support (Barczak and Tadolini 2006) 
Barczak and Tadolini indicate that in the case of using GRC for shield design, the following elements occurring in a longwall panel ought to be taken into account: coal in the longwall panel ahead of the shields and the gob behind the face. Shield support does not affect the parameters of these two elements. The authors also described the various negative effects resulting from an increase in shield capacity, including the following: an increase in shield stiffness, an increase of forces in lemniscate links, or a higher toe base pressure. They stated that a stiffer support will develop more loading than a softer support under the same load conditions.

The indicated benefits of using the GRC concept in the selection of shield parameters for specific mining conditions prompted the authors of this paper to make an attempt to apply this concept to the conditions of Polish underground hard coal mines. To accomplish this purpose, the results of underground tests of shield support carried out in two longwall retreat panels with roof caving are used. The underground studies were performed under the Geomechanics and Control of Soft Mine Floors and Sides (GEOSOFT) project undertaken between 2010 and 2013. The project was co-financed by the Research Fund for Coal and Steel (RFCR-CT-2010-00001) and Ministry of Science and Higher Education. The objective of this project was to determine the influence of the floorbearing capacity on shield performance and roof maintenance in longwall faces. In one specially prepared shield, called "measuring shield" in this paper, changes of the leg pressures were collected. In addition, the changes of inclination of the selected shield elements were measured using inclinometers. The courses of the GRCs were calculated for two longwall faces by means of numerical modeling. Numerical computations were performed using Phase $^{2}$ software, using the Coulomb-Mohr stress criterion.

\section{Underground measurements of selected shield parameters in two longwall panels with roof caving}

To assess the shield performance in two retreat longwalls with roof caving, measurements of the pressure in legs and changes in the inclinations of selected shield elements were carried out. Longwall panels (faces), in this paper named as "A" and "B," were located in the same seam at a similar depth of cover, at 400 and $420 \mathrm{~m}$, respectively. In order to measure the shield pressure, sensors and inclinometers were installed. The arrangement of the inclinometers enabled the determination of changes in shield geometry, including changes in shield height. Measurements were performed in a continuous manner using special apparatus built on the basis of elements an automation system Betacontrol and Mincos (www.beckermining.com.pl). The ground and mining conditions in the longwall panels $\mathrm{A}$ and $\mathrm{B}$, the measurement system used, and selected examples of the results are presented in
"Characteristics of geological and mining conditions in longwall panels A and B," "Characteristics of the measuring shield and the method of underground measurements," and "Results of underground measurements of the legs' pressure and changes in shield heights in longwalls A and B" sections.

\section{Characteristics of geological and mining conditions in longwall panels $A$ and $B$}

\section{Longwall panel A}

Longwall panel A was the first in the mining block and was therefore surrounded by solid (unmined) coal on both sides. The longwall panel width and length were 200 and $840 \mathrm{~m}$, respectively. The cutting height varied from 2.2 to $3.2 \mathrm{~m}$. The longwall face was retreated with natural roof caving into the gob. The depth of cover was approximately $400 \mathrm{~m}$, and the seam inclination was between $5^{\circ}$ and $9^{\circ}$. The immediate roof of the seam consists of the following layers: shale, sandstone, shale, coal, shale, and sandstone, respectively (Fig. 4).

The values of uniaxial compression strength (UCS) of rock layers were relatively low and generally did not exceed $10 \mathrm{MPa}$. In the immediate seam floor, there was shale and sandy shale with an underlying layer of sandstone, as shown in Fig. 4a. In longwall face A, to support the roof, two-leg shields $(2 \times 244$-t capacity) were used.

The basic parameters of the two-leg shields used in longwall working A are as follows:

\begin{tabular}{ll}
\hline - Construction height range & $1.7-3.3 \mathrm{~m}$ \\
- Operational height range & $1.9-3.2 \mathrm{~m}$ \\
- Width & $1.5 \mathrm{~m}$ \\
- Leg diameter (ø) & $0.275 \mathrm{~m}$ \\
- Leg load at setting & $148.0 \mathrm{t}$ \\
- Leg load at yield & $244.0 \mathrm{t}$ \\
- Leg set/yield ratio & 0.606 \\
- Shield setting load density (SLD) & $56.5 \mathrm{t} / \mathrm{m}^{2}$ \\
- Shield yield load density (YLD) & $93.2 \mathrm{t} / \mathrm{m}^{2}$ \\
- Shield setting pressure & $250.0 \mathrm{bar}$ \\
\hline
\end{tabular}

\section{Longwall panel B}

Longwall panel B was the third in the mining block; it was surrounded by a gob on one side (adjacent longwall panel has been mined) and by solid coal on the second side (Fig. 4b). The longwall panel width and length were 230 and $885 \mathrm{~m}$, respectively. The cutting height was approximately $2.9 \mathrm{~m}$. The longwall face was retreated with natural roof caving into the gob. The depth of cover was about $420 \mathrm{~m}$, and the seam inclination was between $4^{\circ}$ and $9^{\circ}$. 


\section{Profile "A"}

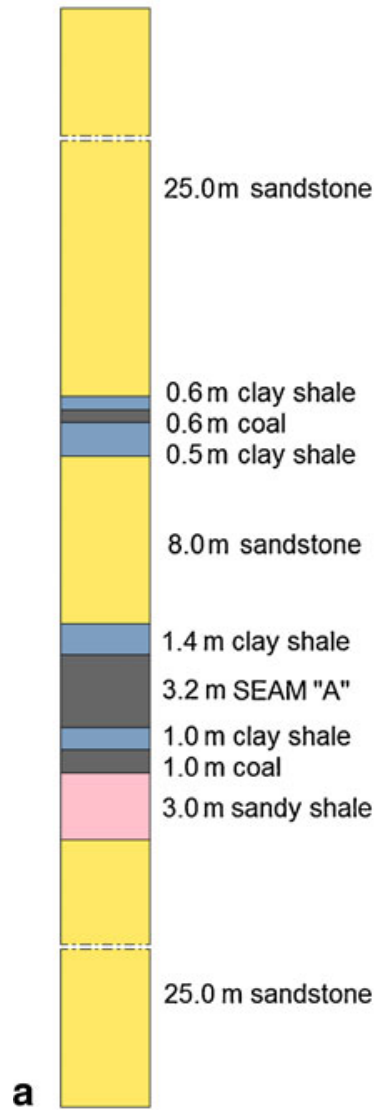

Profile "B"

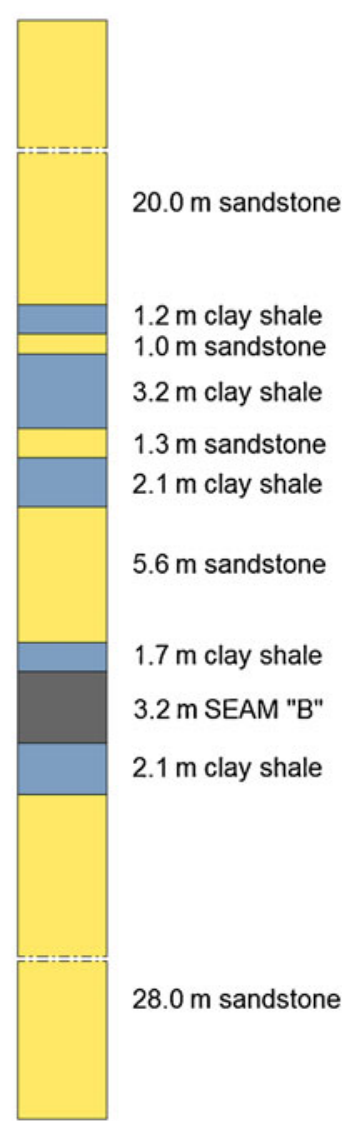

Fig. 4 Profiles of roof and floor layers in the vicinity of the extracted coal seams: a longwall "A" and $\mathbf{b}$ longwall "B"

Longwall panel B roof seam consisted of shale with overlying sandstone and an above layer of sandy shale, sandstone, and shale. The values of uniaxial compression strength (UCS) of the rock layers were low as in longwall panel A and did not exceed $12 \mathrm{MPa}$. In the immediate seam floor, there was shale with underlying layers of varigrained sandstone, as shown in Fig. 4b. For roof maintenance in the working in longwall panel B, two-leg shields $(2 \times 346-t$ capacity $)$ were employed.

Fundamental parameters of the two-leg shield used in longwall working B are as follows:

\begin{tabular}{ll}
\hline - Construction height range & $1.8-3.0 \mathrm{~m}$ \\
- Operational height range & $2.0-2.9 \mathrm{~m}$ \\
- Width & $1.5 \mathrm{~m}$ \\
- Leg diameter (ø) & $0.32 \mathrm{~m}$ \\
- Leg load at setting & $201.1 \mathrm{t}$ \\
- Leg load at yield & $345.8 \mathrm{t}$ \\
- Leg set/yield ratio & 0.581 \\
- Shield setting load density (SLD) & $68.6 \mathrm{t} / \mathrm{m}^{2}$ \\
- Shield yield load density (YLD) & $118.4 \mathrm{t} / \mathrm{m}^{2}$ \\
- Shield setting pressure & $250.0 \mathrm{bar}$ \\
\hline
\end{tabular}

In both longwalls, a bi-directional (bi-di) cutting method was employed. In longwall workings, there is a shearer cut in one direction with a full web depth in the outbound trip and travelling empty in the return trip. Shields employed in longwalls A and B were controlled manually by operators.

Average daily retreat rates in longwall faces A and B were 5 and $6 \mathrm{~m} /$ day, respectively. In the area of longwalls A and B, no seismic events occurred.

\section{Characteristics of the measuring shield and the method of underground measurements}

In this paper, the results obtained from a GEOSOFT project (GEOSOFT 2010-2013) are used. The measuring shield equipped with pressure sensors and inclinometers (Płonka 2013) was placed against longwall panels A and B (Fig. 4). The basic parameters of the measuring shield were as follows:

- Construction height range

$1.6-3.4 \mathrm{~m}$

- Operational height range

$2.0-3.2 \mathrm{~m}$

• Width

- Leg diameter (ø)

$1.5 \mathrm{~m}$

- Leg load at setting

$0.3 \mathrm{~m}$

- Leg load at yield

$176.7 \mathrm{t}$

- Leg set/yield ratio

$240.3 \mathrm{t}$

- Shield setting load density (SLD)

0.581

- Shield yield load density (YLD)

$68.5 \mathrm{t} / \mathrm{m}^{2}$

- Shield setting pressure

$93.1 \mathrm{t} / \mathrm{m}^{2}$

250.0 bar

The measuring shield worked in longwall A as shield no. 119 (about $22 \mathrm{~m}$ from the longwall entry, from the tail gate side) and in longwall B as shield no. 20 (about $31 \mathrm{~m}$ from the longwall entry, from the tail gate side).

In longwall panel A, measurements were performed over a period of 4 months (the panel was retreated by approx. $340 \mathrm{~m}$ ), while in longwall panel $\mathrm{B}$, the duration of the measurements was 11 months (the panel was retreated by approx. $885 \mathrm{~m})$. The values of the shield setting load density $\left[\mathrm{t} / \mathrm{m}^{2}\right]$ and shield yield load density $\left[t / \mathrm{m}^{2}\right]$, presented for the basic shields used for longwalls A and B ("Characteristics of geological and mining conditions in longwall panels A and B" section of the paper) and for the measuring shield, have been calculated taking into account the values of the leg loads at setting or yielding, divided by the roof area supported by the shield canopy.

In longwalls $\mathrm{A}$ and $\mathrm{B}$, the pressure measurement in the legs and changes of inclinations in the measuring shield were performed every second. Inclinations of the shield elements were measured using five inclinometers mounted on the following: base, canopy, front lemniscate link, caving shield, and one of the hydraulic props, as shown in Fig. 5. 
Fig. 5 Distribution of inclinometers at the measuring shield: a canopy, b caving shield, c front lemniscate link, $\mathbf{d}$ hydraulic leg, and e base (Prusek et al. 2013)

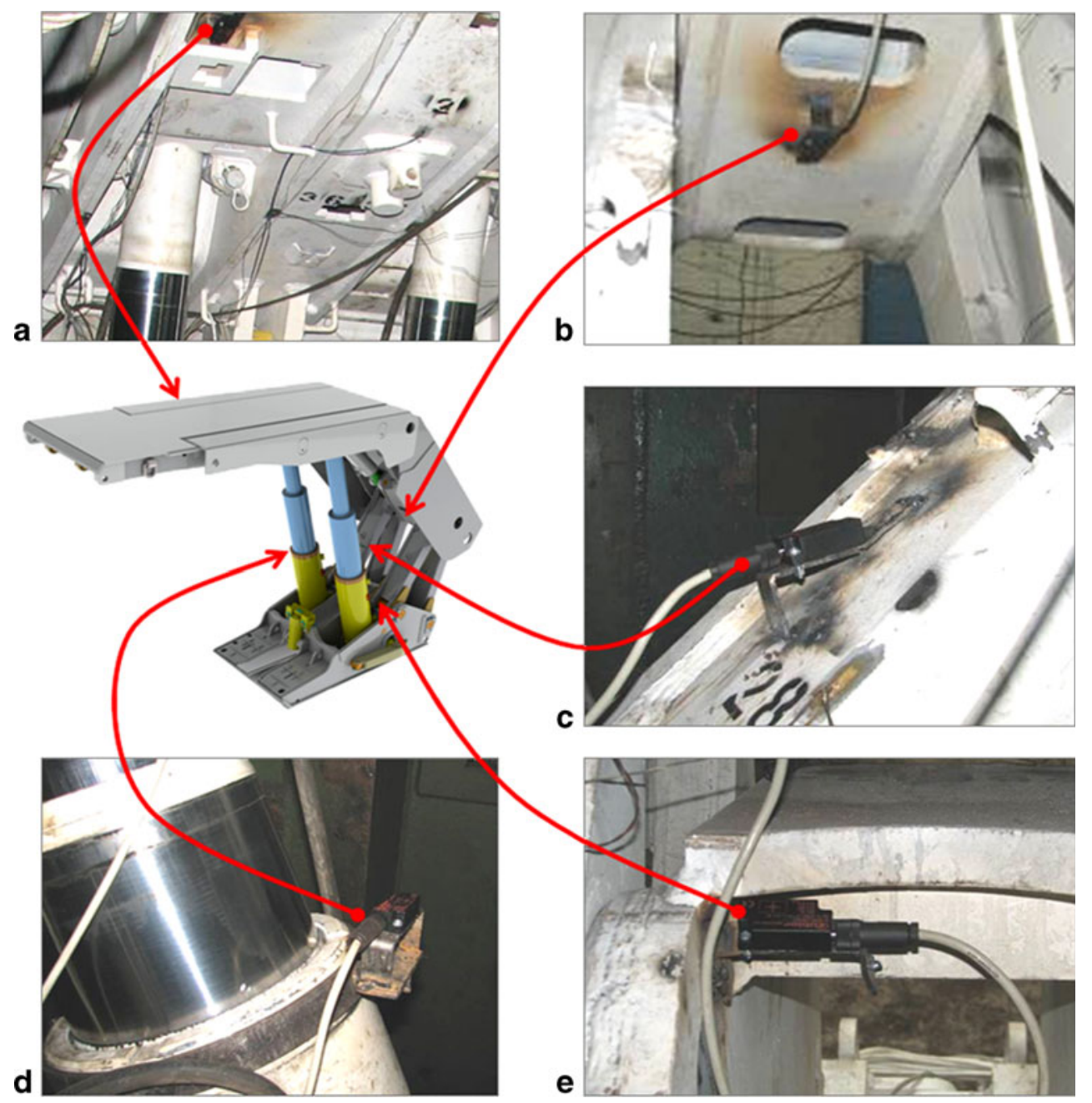

\section{Results of underground measurements of the legs' pressure and changes in shield heights in longwalls A and $B$}

Based on a large number of leg pressure data collected and results obtained from inclinometers, the load exerted on support and changes in shield height for a single shield load cycle in longwalls A and B were determined. Points A to F which characterize the cycle loading pattern (Fig. 3) were similar to those adopted in Barczak and Tadolini (2005):

- $\mathrm{A}-\mathrm{B}$ - shield setting; pressure in legs increase.

- $\mathrm{B}-\mathrm{E}$ - support loading, including points D; pressure increase in legs due to shearer cut as well as $\mathrm{C}$ and $\mathrm{E}$ increase of pressure in legs due to the release of adjacent shields.

- $\quad$ E-F-shield lowering. From point F, there is a shield advance in the longwall face to its initial position (point A).

Figures 6, 7, and 8 are plots of the measured data showing the changes in shield load and height in longwall faces A and
B. Changes in load were obtained from analyses and calculations of the pressure recorded in the shield legs and converted to $1 \mathrm{~m}^{2}$ of the canopy area.

When analyzing the selected examples of a full load cycle of the measuring shield in longwall faces A and B, as demonstrated in Figs. 6 and 8, it can be noted that in face A, the load cycle of a shield lasted twice as long and was approximately $230 \mathrm{~min}$ compared to $100 \mathrm{~min}$ in face B. In both faces, the measuring shield and other shields employed in these workings were set against the roof manually by operators. The results obtained indicate that in both faces, the required (designed) shield setting load density (SLD) $68.5 \mathrm{t} / \mathrm{m}^{2}$ was not reached. In longwall face $\mathrm{A}$, when the shield was being set against the roof (point B), the SLD was about $15 \mathrm{t} / \mathrm{m}^{2}$. In longwall face B, the SLD slightly exceeded $40 \mathrm{t} / \mathrm{m}^{2}$. From the moment of shield setting (point B), the canopy touches the roof and shield load increase is visible. At point $C$, an increase in the shield load is due to the reset and advance of the adjacent shields. Then, the longest and relatively stable shield load cycle took place in the faces from points $C$ to $D$. This is a period of stable shield-roof strata interaction at a moderate 
Fig. 6 An example of changes in shield load and height from measurements in longwall " $\mathrm{A}$ " during a single load cycle (from shield advance to shield lowering)

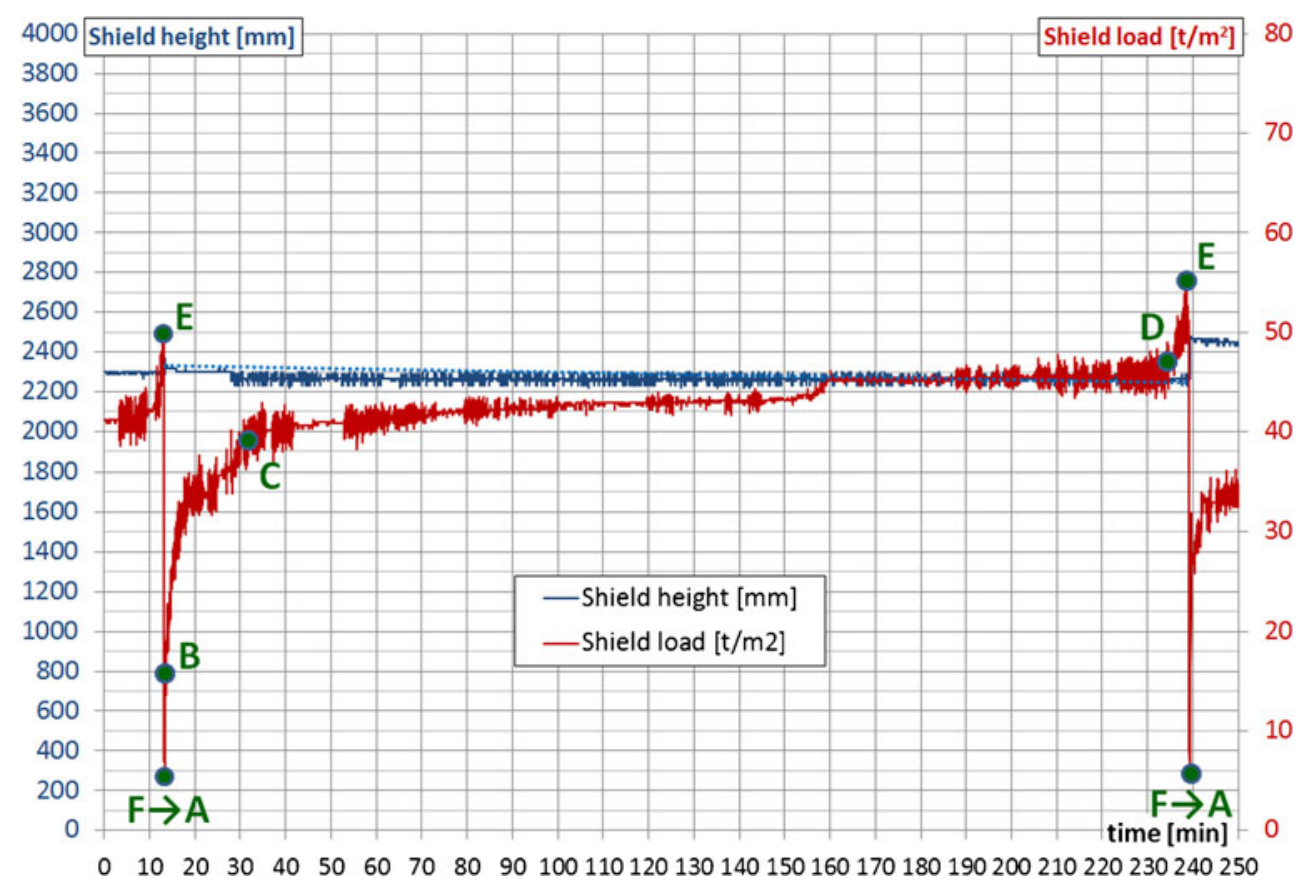

roof convergence. At point $\mathrm{D}$, shield load increases after the shearer face cut is visible. Point $\mathrm{E}$ indicates an increase in load due to the lowering of the immediately adjacent shield after the shearer cut.

In the following parts of this paper, points $\mathrm{B}$ and $\mathrm{E}$ will be referred to as initial SLD and final load density, respectively. The characteristics of shield load variations, illustrated in Figs. 6 and 8, correspond to the steady type of pressure changes, in accordance with the types of pressure changes in the shield supporting cycle defined by Peng (Peng 2006). The characteristic feature of the steady type is the occurrence, in the long term, of an almost flat section in the course of the shield legs' pressure changes from the shield setting to the impact of the approaching shearer (slightly above point $\mathrm{C}$ to point $\mathrm{D}$ ). During this period, the shield has already touched the roof and the pressure in the legs (shield load) increases due to roof convergence.

Figures 6 and 8 also show that in the shield supporting (load) cycles analyzed, in both longwall faces A and B, yielding events in the shield legs did not occur. This indicates that
Fig. 7 An example of load and height changes from measurements on shield in longwall face " $\mathrm{A}$ " during shield advance $(F-A)$ and setting $(A-B)$

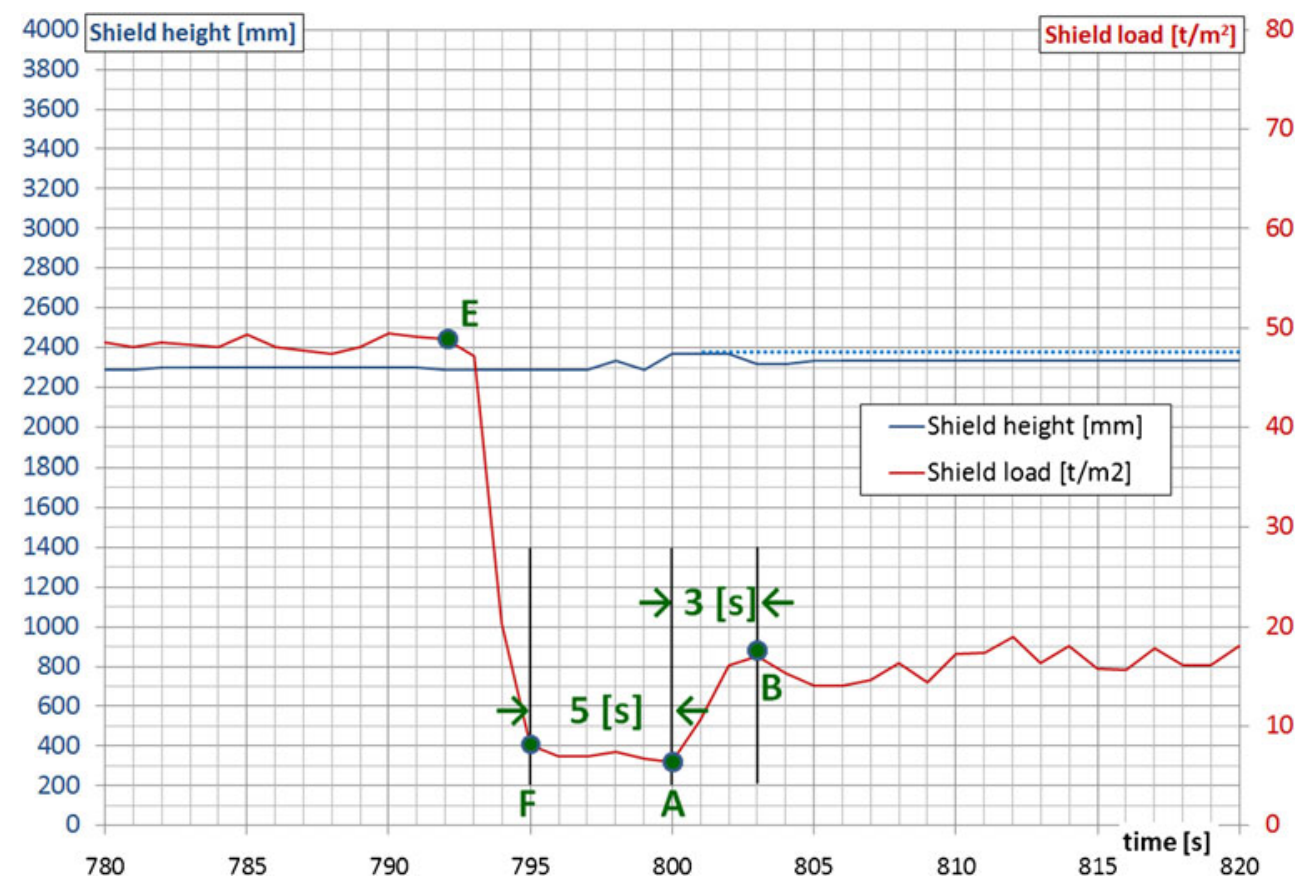


Fig. 8 An example of load and height change from measuring shield in longwall " $\mathrm{B}$ " during a single load cycle (from shield advance to shield lowering)

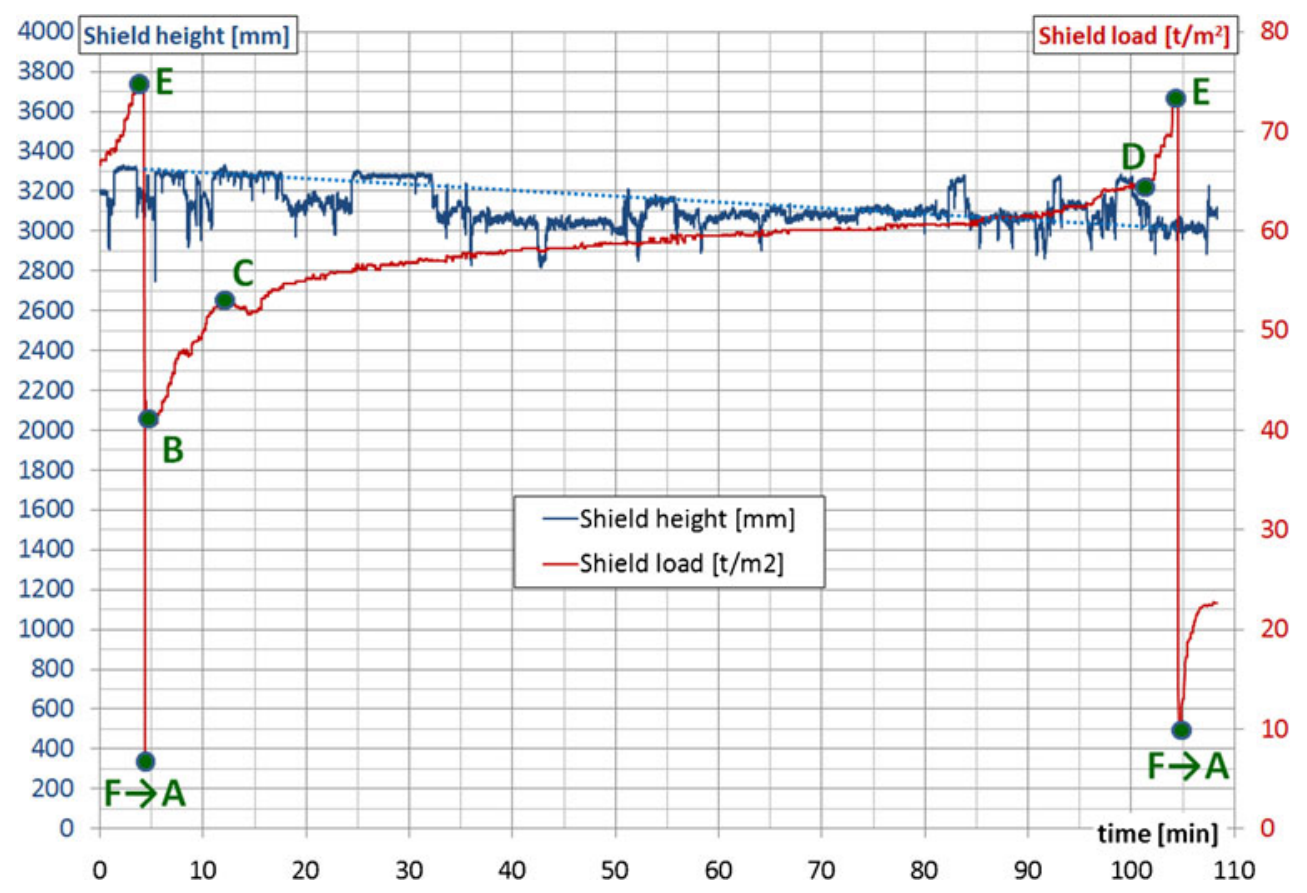

$\tau$ Shear strength (MPa)

$c$ Cohesive strength $(\mathrm{MPa})$

$\sigma \quad$ Normal stress (MPa)

$\phi \quad$ Friction angle $\left({ }^{\circ}\right)$

The basis for carrying out numerical calculations to define the GRCs for the analyzed longwalls was the correct mapping of the geological conditions existing in the area of the analyzed rock mass. It is important to correctly recognize the type, thickness, and the rock layers' sequence in the vicinity of the working. With this in mind, for both cases, numerical modeling of rock masses was performed in the form of discs with a length of $75 \mathrm{~m}$ and a height of $70 \mathrm{~m}$. The arrangement of the rock layers surrounding the longwall working was adopted on the basis of data obtained from the mine. Geological profiles of the rocks for longwalls A and B are shown in Fig. 3.

A numerical model of the rock mass around longwall A, for which numerical calculations were carried out, is presented in Fig. 9.

The mechanical properties of rock strata, including those describing the Mohr-Coulomb criterion Table 1), were adopted based on results of rock strength tests conducted in the area of retreated longwall panels using RocLab (Hoek 2007). It was also assumed that each rock stratum modeled behaves as an elastic-plastic isotropic medium.

Important assumptions adopted in numerical modeling include the appropriate selection of the far field stress state acting on the disc of the rock mass. The values of these stresses were determined from the relationship derived from the generalized Terzaghi and Richart (1952)

$\sigma_{\mathrm{v}}=\gamma \cdot z, \mathrm{MPa}$

where 
Fig. 9 Numerical model of the rock mass around longwall A: $(a)$ longwall "A" longwall "A" and (b) goaf of

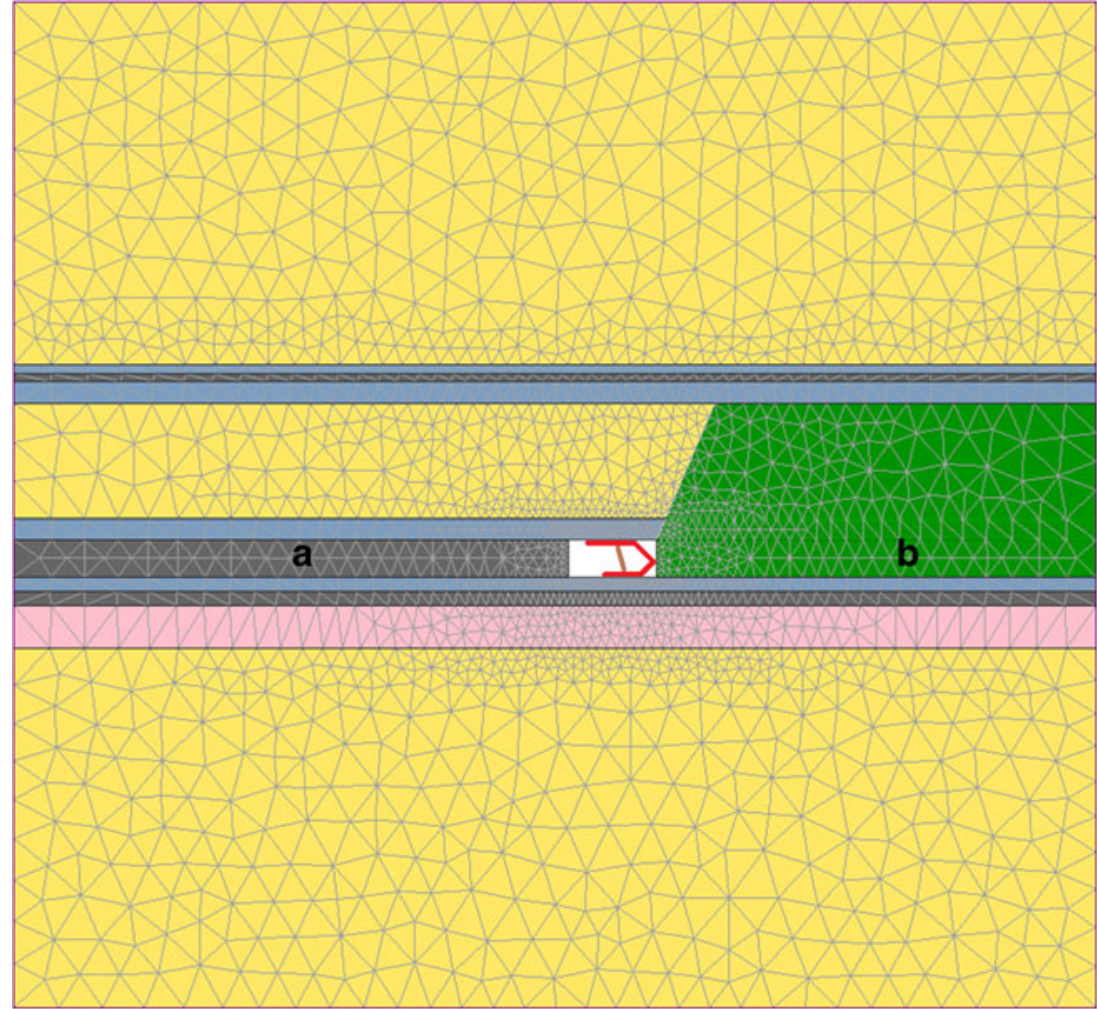

$\sigma_{\mathrm{h}}=\frac{p_{z}}{m-1}, \mathrm{MPa}$

that the ratio of horizontal to vertical stress, expressed as the coefficient $k=\sigma_{\mathrm{h}} / \sigma_{\mathrm{v}}$, largely depends on the depth. The value of the coefficient $k$ ranges from 0.4 to 3.5 (depends on the depth of cover). In the experiments of rock mass numerical modeling in the conditions of Polish mines, the coefficient value $k=1$ is most commonly accepted for calculations and implies a hydrostatic stress state. Accordingly, it is assumed that for longwall panel $\mathrm{A}$, the values of the vertical and horizontal stresses are equal and amount to $\sigma_{\mathrm{v}}=\sigma_{\mathrm{h}}=10.0 \mathrm{MPa}$, while for longwall panel $\mathrm{B}, \sigma_{\mathrm{v}}=\sigma_{\mathrm{h}}=10.5 \mathrm{MPa}$.

Another important factor affecting the results of rock mass modeling in the longwall panels is properly selecting the caving area parameters such as the following: angle of the caving edge, the range of the caving zone, and the gob parameters.

Table 1 Fundamental parameters of rock layers used in the numerical modeling

\begin{tabular}{|c|c|c|c|c|c|c|c|}
\hline Model & Types of rocks & $\begin{array}{l}\text { Young's } \\
\text { modulus } \\
(\mathrm{MPa})\end{array}$ & $\begin{array}{l}\text { Poisson's } \\
\text { ratio } v\end{array}$ & $\begin{array}{l}\text { Tensile } \\
\text { strength } \\
(\mathrm{MPa})\end{array}$ & $\begin{array}{l}\text { Cohesion } \\
(\mathrm{MPa})\end{array}$ & $\begin{array}{l}\text { Friction } \\
\text { angle }\left(^{\circ}\right)\end{array}$ & $\begin{array}{l}\text { Dilatation } \\
\left({ }^{\circ}\right)\end{array}$ \\
\hline \multirow[t]{4}{*}{ Longwall panel "A" } & Coal & 1300 & 0.30 & -0.014 & 0.31 & 23 & 2 \\
\hline & Clay shale & 2118 & 0.23 & -0.011 & 0.45 & 28 & 4 \\
\hline & Sandy shale & 2822 & 0.23 & -0.010 & 0.25 & 30 & 4 \\
\hline & Sandstone & 4187 & 0.20 & -0.021 & 0.52 & 32 & 5 \\
\hline \multirow[t]{3}{*}{ Longwall panel "B" } & Coal & 1100 & 0.30 & -0.013 & 0.30 & 23 & 2 \\
\hline & Clay shale & 2110 & 0.23 & -0.010 & 0.44 & 28 & 4 \\
\hline & Sandstone & 4085 & 0.20 & -0.023 & 0.53 & 32 & 5 \\
\hline
\end{tabular}


When considering the caving angle, there are many different publications indicating its various values (Das 2000; Hosseini et al. 2013). A wide range of research performed in Indian underground coal mines shows that the value of this angle depends on the type of rock and its strength. In a very weak sandstone roof, the caving angle is around $75^{\circ}-90^{\circ}$, whereas in a moderately stronger, massive sandstone roof, the caving angle varied from $27^{\circ}$ to $35^{\circ}$.

Many years of Polish mining experience in the field of coal seam methane drainage were utilized in the calculations for longwall panels A and B. For the purposes of the proper design of methane drainage holes, it was found that the caving angle is usually about $60^{\circ}$ in Polish conditions (Krause and Łukowicz 2013).

The height of the caving zone was calculated by means of the formula (Bai et al. 1995):

$H_{c}=\frac{100 \cdot M}{a \cdot M+b}+c$

where

$H_{c} \quad$ Maximum height of strata caving (m)

$M \quad$ Extracted seam thickness (m)

$a, b \quad$ Coefficients depending on rock dilation and lithology

$c \quad$ Mean square deviation

In the case of longwall panels $\mathrm{A}$ and $\mathrm{B}$ under analysis, the calculated height of the caving zone according to Eq. (2) was $7.0 \mathrm{~m}$. Mechanical parameters of the caving gobs were adopted in accordance with the conditions in longwalls A and B according to Tajduś and Cała (1999) as follows: Young's modulus $E=700 \mathrm{MPa}$, Poisson's ratio $v=0.4$, tensile strength $=0.08 \mathrm{MPa}$, cohesion $=0.08 \mathrm{MPa}$, friction angle $=15^{\circ}$, and dilatation $=0^{\circ}$.

In addition, the following assumptions were adopted in the numerical models:

- Displacement on the horizontal edges of the model disk in the vertical and horizontal direction is equal to zero.

- Displacement on the vertical edges of the model disk in the horizontal direction is equal to zero, and in the vertical direction, they have been released.

- For each longwall panel, the rock mass model and, then, the calculations were carried out twice: the first before the shear cut and the second after the shearer cut (after mining the body of coal).

The results of the calculations of the rock mass response curves for longwall panels A and B from the numerical modeling are presented in Fig. 10. In both cases, the obtained curves show the situation before and after the shearer cut. It should also be noted that these curves were calculated for maximum roof convergence in the longwall workings at a distance of
$4.0 \mathrm{~m}$ from the coal faces (in situations before shearer cut) and at a distance $4.8 \mathrm{~m}$ (in situation after shearer cut).

When analyzing the obtained GRCs for longwall faces A and $\mathrm{B}$, they are characterized by an elastic phase of rock mass deformation in the initial steep part of the GRCs. In these sections of the GRCs, the support load is between 1000 and $450 \mathrm{t} / \mathrm{m}^{2}$. The impact of the shield capacity on roof convergence is minimal. Then, a drop of the GRCs is observed as a result of rock mass transition from elastic to plastic state. Roof convergence occurs at shield support capacity under, approximately, $400 \mathrm{t} / \mathrm{m}^{2}$. In Fig. 10, the designed shield setting load density (SLD), $68.5 \mathrm{t} / \mathrm{m}^{2}$, and shield yield load density (YLD), $93.1 \mathrm{t} / \mathrm{m}^{2}$, were shown.

\section{Comparison of the result of underground tests and the GRC courses for longwall panels $A$ and $B$}

Underground measurements, carried out for 4 months in longwall $\mathrm{A}$ and for 11 months in longwall $\mathrm{B}$, made available large amounts of data including shield leg pressure changes and changes of inclination of its basic components. This data was processed in order to assess shield load and changes of shield height in two longwalls during shield advance, setting, loading, and lowering. The results are shown in Figs. 6, 7, and 8. Three points were selected out of the full shield load changes shown in Figs. 6 and 8, namely the following: point A-the beginning of shield setting, point B-the initial SLD, and point E-the final load density, before shield lowering. Figures 11 and 12 present ten simplified shield load characteristics of the measuring shield for the two longwalls (longwall A and B) with characteristics of GRCs. For plotting the graphs, it was assumed that shield load changes will be connected in their end points E, with GRC characteristics after the shearer cut. Furthermore, it was assumed that the change in shield height determined on the basis of inclinometer indications is equal to the value of the roof convergence in the longwall faces.

It is possible to observe different characteristics of the longwall faces when analyzing the shield load changes, as illustrated in Fig. 10. Among these characteristics are all three major types of pressure changes that can occur within a mining cycle, namely the following: increasing, steady, and decreasing types, as defined by Peng (2006). In the case of longwall A, increasing pressure changes are dominant as shown in characteristic nos. 1-9. Characteristic number 10 represents steady pressure changes. Figure 11 shows that in longwall face A, initial roof convergence ranged from $115 \mathrm{~mm}$ (characteristic no. 1) to $235 \mathrm{~mm}$ (characteristic no. 10), whereas final roof convergence varied from $152 \mathrm{~mm}$ (characteristic no. 2) to $317 \mathrm{~mm}$ (characteristic no. 10). The values of initial SLD were between $13.5^{2}$ and $61 \mathrm{t} / \mathrm{m}^{2}$, while the final load density ranged from 22 to $82 \mathrm{t} / \mathrm{m}^{2}$. In the case of longwall face 
Fig. 10 Ground reaction curves for longwall panels "A" and "B" determined from numerical modeling - situations in the longwall before and after shearer cut; 1 - shield setting load density (SLD), 2-shield yield load density (YLD)

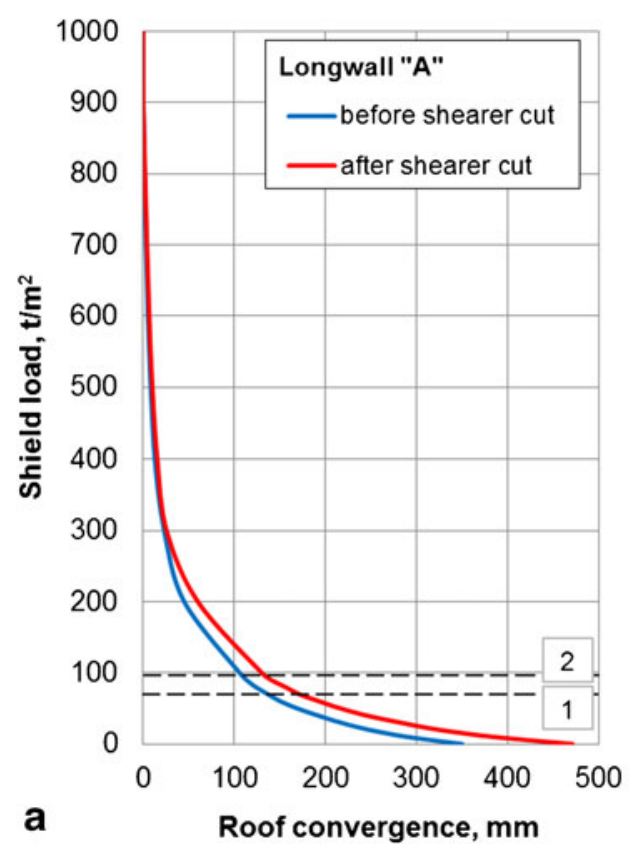

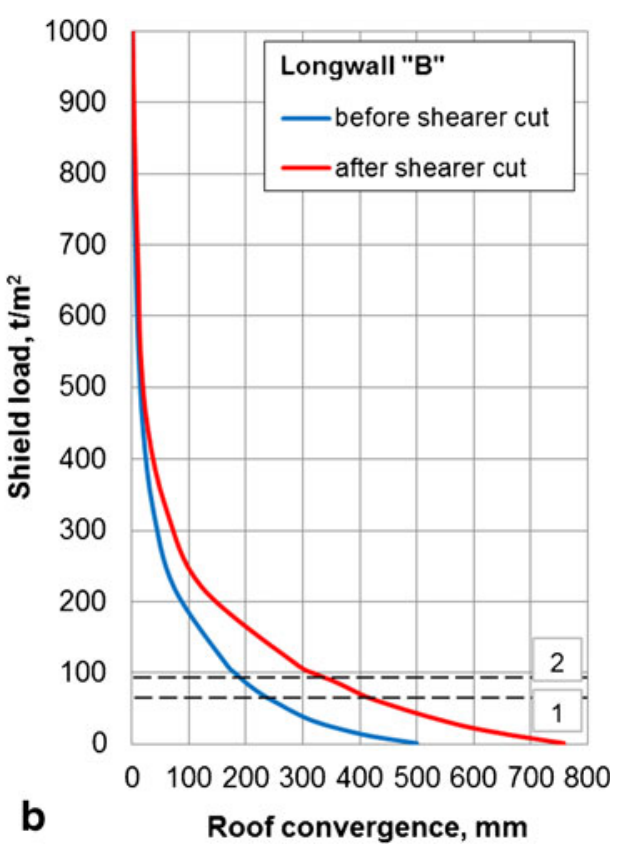

B (Fig. 12), initial roof convergence varied from $40 \mathrm{~mm}$ (characteristic no. 1) to $380 \mathrm{~mm}$ (characteristic no. 10) whilst the final roof convergence ranging from $327 \mathrm{~mm}$ (characteristic no. 4) to $480 \mathrm{~mm}$ (characteristic no. 10). The initial SLD ranged from 30 to $54 \mathrm{t} / \mathrm{m}^{2}$, whereas final load density oscillated between 47 and $97 \mathrm{t} / \mathrm{m}^{2}$. In longwall face $\mathrm{B}$, there were two cases where the value of the shield load (pressure in legs) slightly exceeded YLD (characteristic nos. 3 and 4), resulting in the yield valve opening. In the case of longwall face $B$, the characteristics of shield load (pressure changes in legs) of steady pressure changes (characteristic nos. 1, 2, 5, 6, 7, 8, 9) are dominant. Changes in shield load in this longwall were similar to the characteristics of increasing and decreasing types of pressure change, designated by numbers 3,4 , and 10 , respectively. The probable cause of characteristic no. 10 's decreasing pressure changes, occurring in longwall B, was the local decrease of the floor-bearing capacity parameters (mainly by water inflow), as well as the presence of too much rock/coal debris between the canopy and roof strata. Due to these factors, when the shield was seated against the roof, the initial shield load reached a value of about $53 \mathrm{t} / \mathrm{m}^{2}$ and then started to decrease as a result of shield base penetration in the floor and the crushing of rock/coal debris on the canopy.

When analyzing the characteristics of shield load presented in Figs. 11 and 12, it can be stated that the values of initial SLD are varied, both in longwall A and longwall B. This is mainly due to the manual setting of the measuring shield in faces A and B. In Polish hard coal mines, there are only a few operational longwall faces where the shields are set against the roof by means of automatic setting systems (electrohydraulic systems). Such systems enable the avoidance of insufficient
Fig. 11 Ground reaction curves for longwall panel "A," before and after the shearer cut, with changes of shield load and roof convergence (characteristic nos. $1-10)$

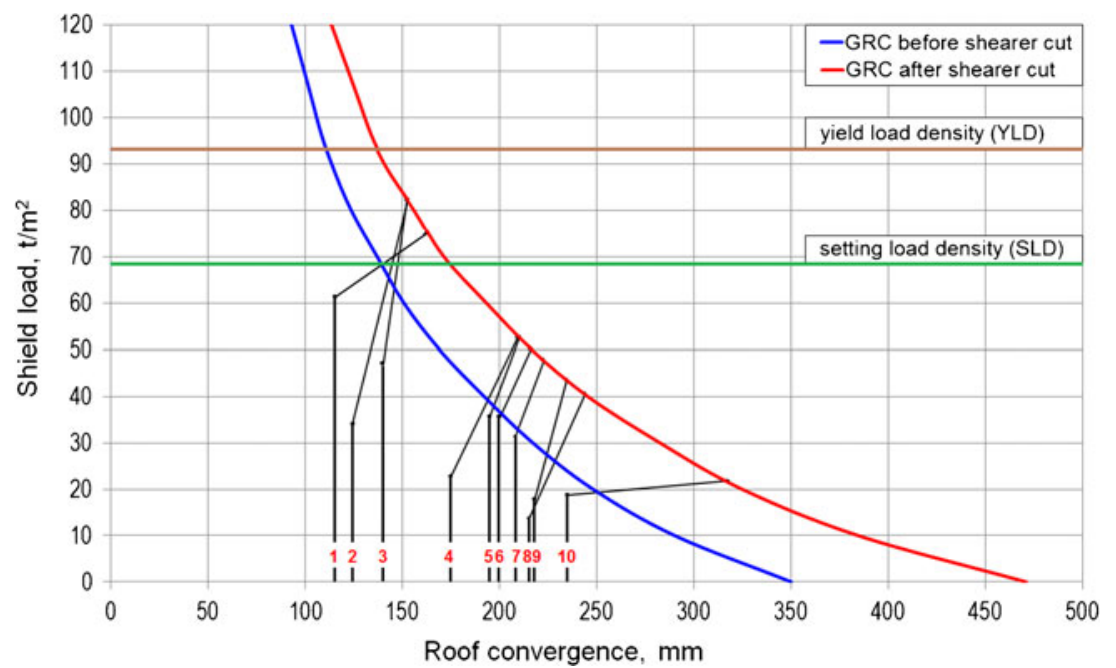


Fig. 12 Ground reaction curves for longwall panel "B," before and after the shearer cut, with changes of shield load and roof convergence (characteristic nos. $1-10)$

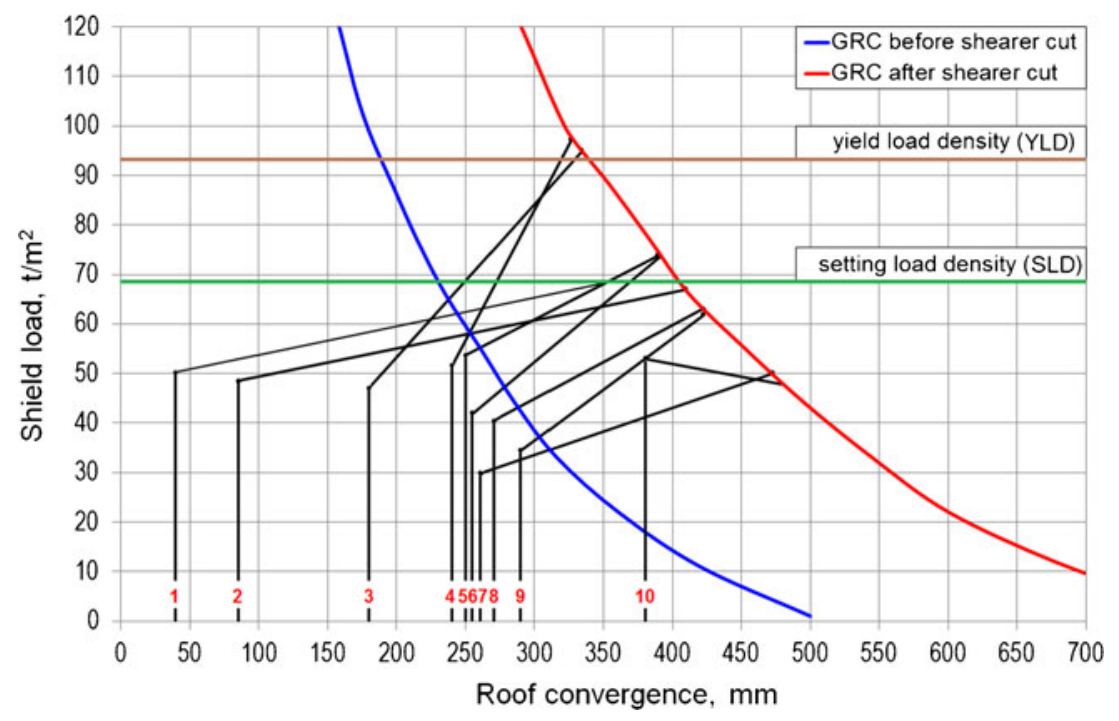

shield setting below the setting pressure in longwall faces. In general, when the shield is set below the recommended setting pressure, adverse events may occur in the longwall workings due to excessive roof convergence such as minor or massive roof falls. The impact of shield capacity on maintaining the roof was described in Trueman et al. (2011), based on an example from Australian underground hard coal mines. In longwall faces $\mathrm{A}$ and $\mathrm{B}$, despite setting the shield against the roof below the recommended setting pressure, no significant problems in maintaining the roof occurred. This most probably resulted from relatively favorable ground and mining conditions, such as not having a high depth of cover in comparison with other Polish mine conditions, a lack of seismic events, and regular roof caving behind the shield line (lack of overhanging roof strata behind the shields).

Figures 13 and 14 present the characteristics of GRCs and the average characteristics of changes in shield load and roof convergence in longwall faces A and B.

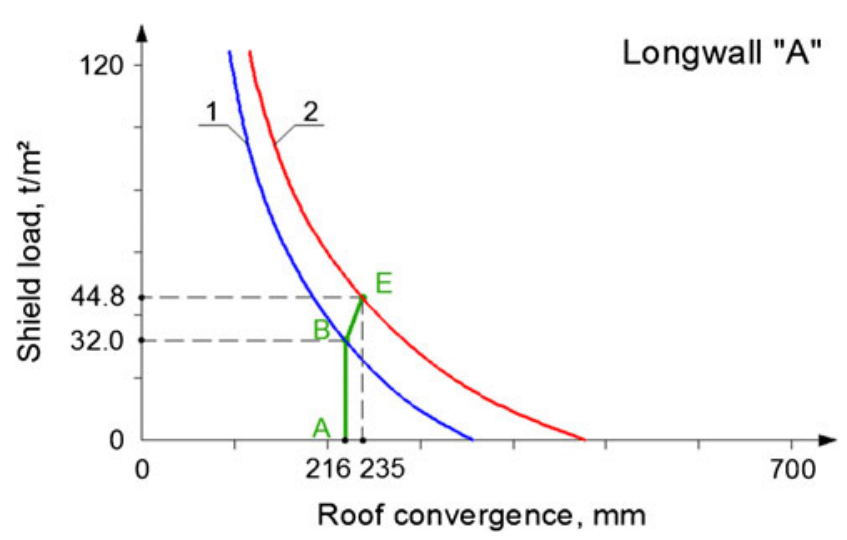

Fig. 13 Average shield load and roof convergence in longwall face "A" with GRC: 1 - GRC before shearer cut; 2 - GRC after shearer cut; $A$ beginning of shield setting, point $B$-initial shield load at setting, and point $E$ - final shield load, before shield lowering
When analyzing the average values of roof convergence and shield load, based on the measurements in longwall faces $\mathrm{A}$ and $\mathrm{B}$, it can be observed that higher initial roof convergence took place in face $\mathrm{B}$ and was equal to $270 \mathrm{~mm}$, in comparison to $216 \mathrm{~mm}$ in face $\mathrm{A}$. In longwall face $\mathrm{B}$, there was also higher roof convergence before and after the shearer cut which amounted to $123 \mathrm{~mm}$. In longwall face A, the average convergence before and after the shearer cut was considerably lower and was equal to $19 \mathrm{~mm}$. Final roof convergence was 235 and $393 \mathrm{~mm}$ in faces A and B, respectively. Taking into account the fact that the values of convergence were determined about $4 \mathrm{~m}$ from the coal faces before the shearer cut and $4.8 \mathrm{~m}$ after the shearer cut, the average relative values of convergence were as follows: for longwall face Aaverage initial roof convergence of $54 \mathrm{~mm} / \mathrm{m}$ and average final roof convergence of $49 \mathrm{~mm} / \mathrm{m}$ and for longwall face B - average initial roof convergence of $67.5 \mathrm{~mm} / \mathrm{m}$ and average final roof convergence of $71 \mathrm{~mm} / \mathrm{m}$. The average values

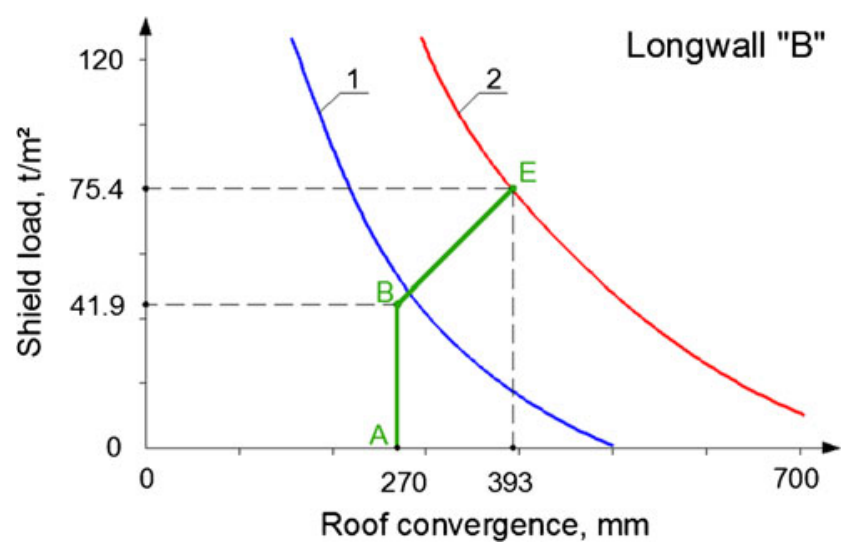

Fig. 14 Average shield load and roof convergence in longwall face "B" together with GRC: 1 - GRC before shearer cut; 2- GRC after shearer cut; $A$ - beginning of shield setting, point $B$ - initial shield load at setting, and point $E$ - final shield load, before shield lowering 
of initial SLD and final load density in face A were 32 and $44.8 \mathrm{t} / \mathrm{m}^{2}$, respectively, whereas in face B, they measured 41.9 and $75.4 \mathrm{t} / \mathrm{m}^{2}$, respectively. These values of initial shield load at setting indicate that the measuring shield was set in longwalls A and B below the setting pressure (below 250 bar). After calculations, it can be stated that the average setting pressure in face A was 120 bar while in face B, it was 150 bar. The reason for this was the fact that the shields were set manually, as previously stated.

The factors that had significant impact on the various roof convergences and shield loads in faces A and B are different, for instance, the slightly increased height of longwall working B $(3.2 \mathrm{~m})$ and specific differences in roof and floor stratification (Fig. 4). However, the location of the longwall panels had the greatest influence on this condition. Longwall panel A was surrounded by solid (unmined) coal on both sides, while longwall panel B was surrounded by gob on one side, which is more unfavorable for stability in underground workings.

Certain discrepancies can be found when comparing the absolute and relative average values of roof convergence (calculated for $1 \mathrm{~m}$ of longwall working length) in longwall faces A and $\mathrm{B}$ to findings in other countries. For example, Medhurst (2005), who analyzed Australian underground hard coal mines, states that cavities start to develop in the roof strata when roof convergence is between 30 and $50 \mathrm{~mm}$. When roof convergence exceeds $100 \mathrm{~mm}$, the overlying strata are broken. In longwalls $\mathrm{A}$ and $\mathrm{B}$, roof convergence was higher with no adverse events observed. In these longwall faces, neither minor nor major roof falls occurred nor were any serious obstacles to mining operations (e.g., face instability or stoppages, irregular face advance) encountered. Singh and Singh (2009a), on the basis of longwall working observations and numerical modeling carried out in India, concluded that roof convergence in a longwall working should not exceed $75 \mathrm{~mm} / \mathrm{m}$, and this should form a design criterion for optimal shield selection for the static load condition. This criterion was fulfilled in the case of longwall faces $\mathrm{A}$ and $\mathrm{B}$, where both average initial and final roof convergences did not exceed $75 \mathrm{~mm} / \mathrm{m}$.

\section{Conclusions and recommendation}

This paper shows the use of the GRC concept in the analysis of shield and roof strata interaction in two retreat longwall faces with roof caving in Polish underground coal mines. The longwall panels were retreated at the heights of 2.9 and $3.2 \mathrm{~m}$, respectively, at a depth of cover of about $400 \mathrm{~m}$, in static load conditions. In the two longwall faces studied, the research was conducted using a measuring shield for periods of 4 and 11 months. It has been shown that in cases of manual shield setting, the shield is often not set against the roof with the appropriate amount of initial pressure. At the time of carrying out the measurement in longwalls $\mathrm{A}$ and $\mathrm{B}$, the measuring shield has never reached the recommended value of SLD $\left(68.5 \mathrm{t} / \mathrm{m}^{2}\right)$. The use of an electrohydraulic control system, in which the shield is set against the roof automatically, is without doubt more advantageous.

The results of the measurements of initial and final roof convergences in the longwall faces are presented. Initial convergence ranged from 216 to $270 \mathrm{~mm}$, whereas final convergence was between 235 and $393 \mathrm{~mm}$ in faces A and B, respectively. The values of roof convergence were obtained using measuring shield height variations. This kind of convergence measurements is relatively difficult to carry out for many reasons: the high variability of the situation in the longwall working caused by shearer cutting the coal face, shield advance, and progressive roof caving. While there are many publications on continuous pressure measurement in static shield legs, the results of continuous measurement of convergence in operational longwall faces are relatively rare.

Comparing the absolute average values of roof convergence, it can be concluded that they do not confirm experiences of Australian mines, where, at the values, cavities started to develop in the roof strata or the overlying strata broke (Medhurst 2005). For relative average values of final roof convergence, from $49 \mathrm{~mm} / \mathrm{m}$ in longwall A to $71 \mathrm{~mm} / \mathrm{m}$ in longwall $\mathrm{B}$, the values are consistent with given determined convergence for the conditions in Indian mines. Singh and Singh (2010) concluded that, to maintain stability of the roof in a longwall working, convergence ought not to exceed $75 \mathrm{~mm} / \mathrm{m}$. In longwalls A and B, roof convergence was lower and there were no difficulties in maintaining the roof. The observed differences between experiences of Australian mines and Polish ones show that caution is advised applying empirical criteria for different conditions than the ones that they were determined for.

This paper highlights that during longwall mining, there may be various types of pressure changes in shield legs (shield load) which can be described as increasing, steady, and decreasing types of pressure change. This is particularly noticeable in the case of longwall $\mathrm{B}$. This situation is caused by the variation in ground and mining conditions in the longwall panel as a consequence of the lowering of the roof or floor rock strength parameters, the presence of rock/coal debris on the canopy, or damage to the hydraulic props.

The results of the measurements also indicate that in the case of the first longwall panels in a mining block which are surrounded on both sides by solid coal (longwall panel A), roof convergence and shield load density are smaller when compared to longwall panels surrounded by gob on one side (longwall panel B). The average values of initial SLD and final load density were between 32 and $44.8 \mathrm{t} / \mathrm{m}^{2}$ in longwall A and varied from 41.9 and $75.4 \mathrm{t} / \mathrm{m}^{2}$ in longwall B.

Giving an unequivocal answer to the question "Is bigger better?" posed by Barczak and Tadolini (2006) remains a task. On the one hand, experience gained in Moranbah North mine 
in Australia (where shields with, most probably, the largest possible capacity of $1750 \mathrm{t}$ ) shows that shields of greater capacity reduce the number of roof falls and the downtimes in the production (Martin et al. 2012). On the other hand, the data presented in Singh and Singh (2009a) on Indian coal mines indicate that an increase in shield capacity may result in an increase in the roof convergence in a longwall working located in certain ground and mining conditions. The authors of this paper caution against unjustified increase of shield capacity without proper characterization of the ground and mining conditions in a given longwall panel. It is strongly recommended that a system enabling ground characterization and mining conditions appropriate for shield capacity determination and selection be developed.

Open Access This article is distributed under the terms of the Creative Commons Attribution 4.0 International License (http:// creativecommons.org/licenses/by/4.0/), which permits unrestricted use, distribution, and reproduction in any medium, provided you give appropriate credit to the original author(s) and the source, provide a link to the Creative Commons license, and indicate if changes were made.

\section{References}

Bai M, Kendorski F, Van Roosendaal D (1995) Chinese and North American high-extraction underground coal mining strata behavior and water protection experience and guidelines. Proceedings of 14 th International Conference on Ground Control in Mining, Morgantown

Bai Q-S, Shi-Hao T, Zhang X-G, Zhang C, Yuan Y (2014) Numerical modeling on brittle failure of coal wall in longwall face - a case study. Arab J Geosci 7(12):5067-5080

Barczak TM, Oyler DC (1991) A model of shield-strata interaction and its implications for active shield setting requirements. Report of Investigations 9394. United States Department of the Interior

Barczak TM, Tadolini SC (2006) Longwall shield and standing gateroad support designs - is bigger better? Proceedings of Longwall USA, Pittsburgh, Pennsylvania, June 5-7

Barczak TM, Esterhuizen GS, Ellenberger J, Zahng P (2008) A first step in developing standing roof support design criteria based on ground reaction data for Pittsburgh seam longwall tailgate support. In: Proceedings of the 27th International conference on ground control in mining, West Virginia: 347-357

Biliński A (1976) Criteria of support selection for longwall workings with natural roof caving. Prace GIG, Seria dodatkowa, Katowice (In Polish)

Biliński A (1983) Principles of underground working maintenance in longwalls with rockburst hazard. Archiwum Górnictwa. Tom 28. Zeszyt 2. Kraków (In Polish)

Brady B, Brown E (2006) Rock mechanics for underground mining. The Netherlands, Springer, Third edition 2004, reprinted with corrections

Brown E, Hoek E (1978) Trends in relationship between measured in-situ stresses. Int J Rock Mech Min Sci Geomech Abstr 15:21-215

Carranza-Torres C, Fairhurst C (2000) Application of the convergenceconfinement method of tunnel design to rock masses that satisfy the Hoek-Brown failure criterion. Tunn Undergr Space Technol 15(2): $187-213$
Das SK (2000) Observations and classification of roof strata behaviour over longwall coal mining panels in India. Int J Rock Mech Min Sci 37(4):585-597

Dubois R (1960) Die Abhängigkeit der Konvergenz im Streb von verschiedenen Faktoren. De L'industrie Minerale, Internationaler Kongress für Gebrigsdruckforschung 16-20, Paris:469-488

Esterhuizen GS, Barczak TM (2006) Development of ground response curves for longwall tailgate support design. Colorado, Proceedings of the 41st U.S. Rock Mechanics Symposium:1-10

Frith R (2005) Half a career trying to understand why the roof along the longwall face falls in from time to time? In: Proceedings of the 24th International conference on ground control in mining, West Virginia: $33-43$

Frith R (2013) A holistic examination of the geotechnical design of longwall shields and associated mining risks. In: Proceedings of the 13th Coal Operators' Conference:38-49

Gao F, Stead D, Coggan J (2014) Evaluation of coal longwall caving characteristics using an innovative UDEC Trigon approach. Comput Geotech 55:448-460

GEOSOFT (2010-2013) Geomechanics and control of soft mine floors and sides. Project co-financed by Research Fund for Coal \& Steel. Project no. RFCR-CT-2010-00001, realization in (not published)

Herwig H (1981) Die Wirkung des Gebirgdruckes auf den Hangendzustand im Streb. Glückauf No 117

Hoek E (2007) Practical rock engineering. Rocscience Inc, www. rocscience.com

Holub K, Rusajova J, Holecko J (2011) Particle velocity generated by rockburst during exploitation of the longwall and its impact on the workings. Int J Rock Mech Min Sci 48:942-949

Hosseini N, Goshtasbi K, Oraee-Mirzamani B (2013) Calculation of periodic roof weighting interval in longwall mining using finite element method. Arab J Geosci. doi:10.1007/s12517-013-0859-8

Hoyer D. (2012) Early warning of longwall of cavities using LVA software. In: 12th Coal Operators' Conference, University of Wollongong \& the Australasian Institute of Mining and Metallurgy: 69-77

Hussain MA, Ibrahim AR, Imbay SS (2013) Load calculations and selection of the powered supports based on rock mass classification and other formulae for Abu-Tartur longwall phosphate mining conditions. Journal of Engineering Sciences, Assiut University, Faculty of Engineering, Vol. 41, No. 4, July

Jacobi O (1981) Praxis der Gebirgsbeherrschung. Verlag Glückauf $\mathrm{GmbH}$, Essen

Keim SK, Miller MS (1999) Case study evaluation of geological influences impacting mining conditions at a West Virginia longwall mine. Int J Coal Geol 41:51-71

Krause E, Łukowicz K (2013) Zagrożenia gazowe. Bezpieczeństwo pracy w kopalniach węgla kamiennego, praca zbiorowa pod redakcją Władysława Konopko. Tom 2, Zagrożenia Naturalne:954 (In Polish)

Langosch U, Ruppel U, Wyink U (2003) Longwall roof control by calculation of the shield support requirements. In: Proceedings of the Coal Operators' Conference: $162-172$

Manteqi H, Shahriar K, Torabi R (2012) Prediction of first weighting distance in longwall coal mining by $3 \mathrm{D}$ numerical modeling - a case study. In: Proceedings of the 31 st International Conference on Ground Control in Mining:1-9

Martin K, Kizil M, Canbulat I (2012) Analysing the effectiveness of the 1750 tone shields at Moranbah North Mine. In. 12th Coal Operators' Conference, University of Wollongong \& the Australasian Institute of Mining and Metallurgy:31-41

Medhurst TP (2005) Practical considerations in longwall support behaviour and ground response. Coal Conference 2005 Brisbane, QLD, 26-28 April

Mucho TP, Barczak TM, Dolinar DR, Bower J, Bryja JJ (1999) Design methodology for standing secondary roof support in longwall 
tailgates. In: Proceedings of the 18th International conference on ground control in mining, West Virginia: 136-148

Oreste PP (2003) Analysis of structural interaction in tunnels using the covergence-confinement approach. Tunn Undergr Space Technol $18: 347-363$

Özel R, Ünal E (1998) Support and strata interaction in longwall face. Int J Rock Mech Min Sci 35(4/5):484-485

Payne DA (2008) Crinum Mine, 15 longwalls 40 million tones 45 roof falls - what did we learn? In: Proceedings of the 8th Coal Operators' Conference:22-43

Peng SS (1987) Support capacity and roof behaviour at longwall faces with shield supports, International Journal of Mining and Geological Engineering:29-57

Peng SS (1998): What can a shield leg pressure tell us? Coal Age, March: 54-57

Peng SS (2006) Longwall mining. 2nd Edition. Morgantown

Płonka M (2013) Calculations of ground response curve GRC based on measurements of operational powered roof support in the longwall panels with natural roof caving. Research GIG No 11110333-152, (not published) (In Polish)

Płonka M, Rajwa S (2011) Assessment of powered support loadings in plow and shearer longwalls in regard to the pressure measurements in props. In: Proceedings of the International Mining Forum 2011, LW Bogdanka, Poland, A Balkema Book:221-232

Płonka M, Prusek S, Rułka K (2003) 3D strata model application for the selection method of the support for longwall excavation. III International Conference Mining Techniques: 233-245

Prusek S (2014) The factors causing roof fall occurrences in longwall faces with natural roof caving. Przegląd Górniczy 3:71-78 (In Polish)

Prusek S, Rajwa S, Stoiński K (2005a) Kriterien zur Abschatzung des Risikos von Strebschaden. Glückauf-Forschungshefte nr 3 3:92-95

Prusek S, Rajwa S, Walentek A (2005b) An application of numerical modeling for the assessment of the roof stability between the coal face and the tip of canopy. In: Proceedings of the XII International Scientific Conference - Górnicze Zagrożenia Naturalne. Katowice: 229-252 (In Polish)

Prusek S, Rajwa S, Kasperkiewicz W, Budniok T (2013) Assessment of performance of powered shield support used on weak floor. In: Proceedings of the World Mining Congress, Canada.

Saeedia G, Shahriara K, Rezaia B, Karpuzb C (2008) Numerical modeling of out-of-seam dilution in longwall retreat mining. Int J Rock Mech Min Sci 47(4):533-543

Sastry VR, Nair R (2009) Study of behaviour of workings in longwall panel based on field instrumentation. Int J Min Miner Eng 1(3):232247

Shabanimashcool M, Jing L, Li CC (2014) Discontinuous modeling if stratum cave-in in a longwall coal mine in the Arctic area. Geotech Geol Eng 32:1239-1252

Singh GSP, Singh UK (2009a) A numerical modeling approach for assessment of progressive caving of strata and performance of hydraulic powered support in longwall workings. Comput Geotech 36(7):1142-1156

Singh GSP, Singh UK (2009b) Assessment of dynamic loading and rapid yield valve requirement for shield supports in longwall workings. Trans Inst Min Metall Section A Min Technol 118(1):47-52

Singh GSP, Singh UK (2010) Prediction of caving behavior of strata and optimum rating of hydraulic powered support for longwall workings. Int J Rock Mech Min Sci 47:1-16

Smart BGD, Redfern A (1986) The evaluation of powered support from geological and mining practice specifications information. In: Proceedings of the 27th U.S. Symposium on Rock Mechanics (USRMS), Tuscaloosa, Alabama, Chapter 54- Longwall Face Support

Szweda S (2003) Dynamic action of rock mass on the powered support legs. J Min Sci 39(2):154-161

Tajduś A, Cała M (1999) Określenia parametrów obudowy wyrobisk korytarzowych w oparciu o obliczenia numeryczne. Kraków, AGH, Geotechnika w górnictwie i budownictwie specjalnym:253265 (In Polish)

Terzaghi K, Richart FE (1952) Stresses in rock about cavities. Geotechnique 3:57-90

Trueman R, Lyman G, Cocker A (2009) Longwall roof control through a fundamental understanding of shield-strata interaction. Int J Rock Mech Min Sci 46:371-380

Trueman R, Callan M, Thomas R, Hoyer D (2010) Quantifying the impact of cover depth and panel width on longwall shield-strata interactions. In: Proceedings of the 10th Coal Operators' Conference: 97-107

Trueman R, Thomas R, Hoyer D (2011) Understanding the causes of roof control problems on a longwall face from shield monitoring data- $\mathrm{a}$ case study. In. 11th Underground Coal Operators' Conference, University of Wollongong \& the Australasian Institute of Mining and Metallurgy:40-47.

Wiklund B, Kizil MS, Canbulat I (2011) Development of a cavity prediction model for longwall mining, 11th Underground Coal Operators' Conference, University of Wollongong \& the Australasian Institute of Mining and Metallurgy:48-59

Wilson AH (1975) Support load requirements on longwall faces. Min Eng 134:479-491

Winstanley A (1951) Die Beherrschung des Hangenden im mechanisierten Abbau. International Conference about rock pressure and support in the workings, 24-28 April, Liege: 203-213

Yasitli NE, Unver B (2005) 3D numerical modeling of longwall mining with top-coal caving. Int J Rock Mech Min Sci 42:219-235

Yavuz H (2004) An estimation method for cover pressure reestablishment distance and pressure distribution in the goaf of longwall coal mines. Int J Rock Mech Min Sci 41:193-205, http://www.becker-mining.com.pl 